\title{
Adrenocortical Function in Preterm Infants
}

Hye Rim Chung, M.D., Ph.D.

Department of Pediatrics, Seoul National University Bundang Hospital, Seongnam, Korea

\section{ABSTRACT}

Adrenal hormones are essential for the timely differentiation and maturation of fetal organs and the regulation of intrauterine homeostasis. These hormones play complex roles during fetal life, and they are believed to provide the cellular communication that coordinates maternal-fetal interactions. Cortisol serves to modulate functional adaptations for extrauterine life in the perinatal period. Serum cortisol levels of preterm infants are similar to basal levels reported for healthy full-term neonates. However, a rise of cortisol production is absent during illness. Compared with a fetus of a similar gestational age, premature maturation of the hypothalamic-pituitary-adrenal (HPA) axis is suggested in preterm infants; however, the inappropriate cortisol value observed in severe illness is due to immaturity of $11 \beta$-hydroxylase activity and an immature response of the brain to stress. Cardiovascular instability associated with adrenal insufficiency is more frequent than formerly reported, and replacing glucocorticoids in the treatment of refractory hypotension is effective without an increase in short term adverse consequences. However, the diagnostic criteria and optimal management have not yet been determined. Thus, further understanding of perinatal adrenal function will provide insight into the improved management of preterm infants.

Key Words: Preterm, Adrenal, Cortisol

\section{INTRODUCTION}

The adrenal cortex produces 3 categories of steroid hormone; glucocorticoids, mineralocorticoids, and adrenal androgens. Cortisol is a glucocorticoid, and it regulates a wide variety of physiologic processes from fetal to adult life. In the perinatal period, it serves to modulate functional adaptations for extrauterine life $\mathrm{e}^{\mathrm{1}-4)}$. The main functions of cortisol in the postnatal period are to regulate protein, carbohydrate, lipid, and nucleic acid metabolism; maintain vascular responsiveness to circulating vasoconstrictors and oppose the increase in capillary permeability during acute inflammation; regulate extracellular water by reducing movement of water into cells and promoting free water excretion; suppress the inflammatory response; and modulate central nervous system processing and behavior ${ }^{4,5}$. While the survival rate of preterm infants has improved over recent decades, preterm
Received: 27 June 2015

Revised: 3 August 2015

Accepted: 3 August 2015

Correspondence to:

Hye Rim Chung, M.D., Ph.D.

Department of Pediatrics, Seoul National University Bundang Hospital, 82, Gumi-ro 173 beongil, Bundang-gu, Seongnam 13620, Korea

Tel: +82-31-787-7292

Fax: +82-31-787-4054

E-mail: chyerim@hanmail.net

Copyright(c)

By Korean Society of Neonatology.

All right reserved.

This is an Open-Access article distributed under the terms of the Creative Commons Attribution Non-Commercial License (http://creativecommons.org/licenses/ by-nc/3.0), which permits unrestricted non-commercial use, distribution, and reproduction in any medium, provided the original work is properly cited. 
infants continue to present clinical manifestations associated with an abnormal cortisol axis. Infants with endocrine abnormalities are at increased risk of abnormal development and morbidity $^{2-4)}$.

This article briefly reviews the current understanding of the maturation of the adrenal gland, the roles of cortisol in the neonate's adaptation to extrauterine life, and the interpretation of clinical findings associated with adrenocortical function in preterm infants.

\section{FETAL ADRENAL CORTEX}

The fetal adrenal gland exhibits a remarkable transformation in size, morphology, and function during the fetal and perinatal period $^{1,6)}$. The fetal adrenal gland is composed of three functional zones: a fetal zone (FZ), a transitional zone, and an outer definitive zone. The FZ mainly produces androgenic precursors, the transitional zone contains enzymes for cortisol production, and the definitive zone produces mineralocorticoids ${ }^{1,6)}$. Expression of steroidogenic enzymes from each zone during fetal life is different from those of postnatal life. Because the FZ has relatively high steroid sulfotransferase activity and low 3-beta hydroxysteoid dehydrogenase (3ßHSD) activity, the major steroid products of the fetal adrenal gland are dehydroepiandrosterone (DHEA) and dehydroepiandrosterone sulfate (DHEAS). There is a limited amount of cortisol and aldosterone produced ${ }^{6)}$. There is also complementary activity between the enzymes involved in steroid formation and transformation between the placental and fetal compartments ${ }^{7)}$ (Figure 1).

By 8 weeks gestation, the adrenal gland begins cortisol synthesis, which involves a transient expression of adrenal 3 $3 \mathrm{HSD}$ ${ }^{1,6,8)}$. By 9 weeks gestation, the expression of $3 \beta$ HSD and the synthesis of cortisol decrease, and they are absent at 14 weeks gestation $^{8}$. Before 23 weeks gestation, the human fetal adrenal cortex cannot produce cortisol de novo, and it normally does not do so until as late as 30 weeks gestation ${ }^{1,6,9}$. The fetal cortisol production rate in the blood per unit body weight near term is similar to that

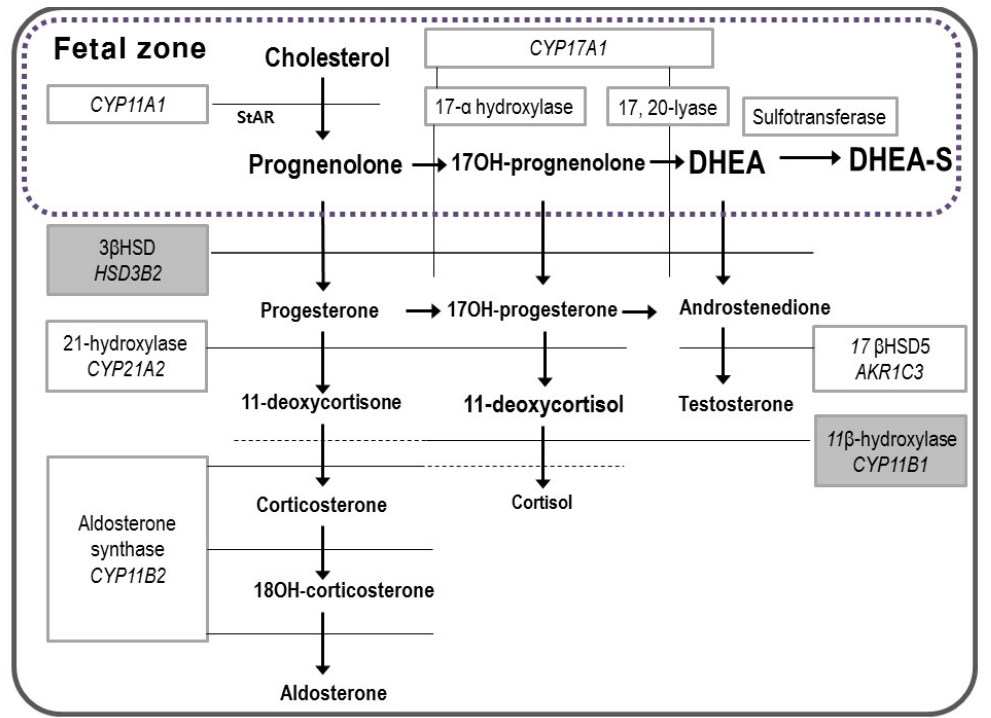

Figure 1. Steroid biosynthesis of fetus and preterm infant. The fetal zone of the human fetal adrenal cortex is capable of performing the reactions in the dotted line box. Since the fetal zone has relatively high steroid sulfotransferase activity, low $3 \beta \mathrm{HSD}$ activity and low $11 \beta \mathrm{HSD}$, the major steroid products of the fetal adrenal gland are DHEA and DHEAS. In contrast, previous studies have shown no evidence of significant immaturity in adrenal $3 \beta$ HSD activity in preterm infants between 24 28 weeks gestation. Decreased activity of $11 \beta$-hydroxylase explains relatively low cortisol levels in preterm infant. Abbreviations: DHEA, dehydroepiandrosterone; DHEA-S, dehydroepiandrosterone sulfate; $3 \beta$ HSD, $3 \beta$-hydroxysteroid dehydrogenase; 11 $\beta$ HSD, $11 \beta$-hydroxysteroid dehydrogenase; 17 $\beta$ HSD, 17 $\beta$-hydroxysteroid dehydrogenase. 
in the adult ${ }^{4,5)}$. Fetal cortisol is converted to cortisone through $11 \beta$-hydroxysteroid dehydrogenase (11ßHSD) in fetal tissues, and levels of circulating cortisone in the fetus at mid-gestation are 4-fold to 5-fold higher than cortisol concentrations ${ }^{10,11)}$. The adrenocorticotropin (ACTH) feedback control system progressively matures during the second half of gestation and early neonatal period ${ }^{5)}$. Maturation of the pituitary portal vascular system continues, and this maturation process extends to 30 to 35 weeks gestation ${ }^{5)}$.

Steroid hormones produced by the fetal adrenal gland play key roles in the maintenance of pregnancy, intrauterine homeostasis, fetal maturation, and the initiation of parturition ${ }^{6)}$.

In the term neonate, the adrenal gland undergoes rapid involution due to the rapid disappearance of the FZ. In contrast, the definitive zone, which contains an inner zona fasciculata and an outer zona glomerulosa, proliferates soon after birth ${ }^{1,6)}$. There is controversy about whether the timing of the fetal adrenal involution is determined by gestation or by birth ${ }^{6)}$.

\section{ROLE OF THE CORTISOL SURGE IN THE TRANSITION TO EXTRAUTERINE LIFE}

After abrupt delivery, the neonate must initiate breathing and defend against hypothermia, hypoglycemia, and hypocalcemia as the placental supply of energy and nutrients are removed. The adrenal cortex rapidly responds to these changes.

Fetal cortisol levels in the human tend to be as low as 5-10 $\mu \mathrm{g} /$ $\mathrm{mL}$ until approximately 30 weeks gestation. Cortisol levels progressively increase to approximately $20 \mu \mathrm{g} / \mathrm{mL}$ by approximately 36 weeks gestation and increase further to approximately $45 \mu \mathrm{g} /$ $\mathrm{mL}$ at term. Cortisol further increases during labor to peak at high levels of approximately $200 \mu \mathrm{g} / \mathrm{ml}$ several hours after a term delivery ${ }^{12)}$. This cortisol surge is mediated by a decreased rate of conversion of cortisol to cortisone and increased cortisol production by the fetal adrenal gland ${ }^{10,12)}$. The cortisol responses to preterm birth are also attenuated because of unresponsiveness and immaturity of the adrenal gland ${ }^{12)}$. In addition, cesarean section without labor at term blunts the postnatal rise in cortisol $^{16)}$.

The cortisol surge augments surfactant synthesis in lung tissue, increases reabsorption of liquid in the lungs, increases the methylation of norepinephrine to epinephrine, increases conversion of thyroxine (T4) to triiodothyronine (T3), facilitates ductus closure, induces maturation of several enzymes and transport pro- cesses of the small intestine, and stimulates the maturation of hepatic enzymes ${ }^{5}$. Prenatal inflammation, such as that observed in chorioamnionitis, leads to adrenal stimulation, which results in increased cortisol secretion ${ }^{14,15)}$.

\section{ADRENOCORTICAL FUNCTION OF PRETERM INFANTS}

Activation of the hypothalamic-pituitary-adrenal (HPA) axis is crucial to maintaining homeostasis in response to stress. Otherwise, the preterm infant would have a limited ability to maintain homeostasis after birth. Developmental immaturity and relative adrenal insufficiency due to illness may contribute to inadequate adrenocortical function. Adrenocortical function in preterm infants is closely related to the duration of gestation ${ }^{16)}$. However, the cortisol production rate, assessed by urinary cortisol metabolites, of preterm infants of less than 30 weeks gestational age approaches the cortisol production rate of older children and adults. A rise in cortisol production is absent in preterm infants during clinical illness ${ }^{17)}$. Cortisol levels are inappropriately low in some ill preterm infants, either due to the inability of the extremely premature brain to recognize the stress of the illness or because of inadequate hypothalamic secretion of corticotropin releasing hormone $(\mathrm{CRH})^{18)}$.

Although the human fetal adrenal cortex does not express the 3ßHSD enzyme before approximately 23 weeks gestation, previous studies have shown no evidence of significant immaturity in adrenal 3 $\beta \mathrm{HSD}$ activity in preterm infants between 24-28 weeks gestation $^{19,20)}$. In contrast, decreased activity of $11 \beta$-hydroxylase, which converts 11-deoxycortisol to cortisol, is prominent. Reduced activity of $11 \beta$-hydroxylase, rather than that of $3 \beta \mathrm{HSD}$, is thought to explain the inappropriate production of cortisol in the preterm adrenal gland ${ }^{19,20)}$ (Figure 1).

Blood concentrations of cortisol and other steroid hormones are not lower in preterm infants with late-onset adrenal insufficiency compared with control preterm infants ${ }^{21)}$. These findings suggest that preterm infants might not have an absolute deficiency of cortisol production but rather a limited ability to synthesize sufficient cortisol for the corresponding degree of clinical stress. 


\section{EVALUATION OF ADRENOCORTICAL FUNCTION IN PRETERM INFANTS}

The assessment of adrenocortical function in preterm infants is necessary, as immaturity of the HPA axis is related to clinical instability during acute stress. However, the best method of assessing adrenal function in preterm infants is still under debate.

The measurement of basal serum cortisol in preterm infants is not sufficient as a method for evaluating the function of the HPA axis. This is due to many influencing factors, such as the degree of stress and the effects of associated diseases. The real 'normal values' of serum cortisol are not available, as these are dependent upon both gestational age and postnatal age ${ }^{2,23)}$. While measuring serum cortisol levels in the early morning is a reliable method to evaluate the HPA axis in adults and children, it is not adequate in young infants, especially in preterm infants because the diurnal variation of cortisol is established during early in fancy in term infants ${ }^{24)}$. Therefore, a dynamic test using ACTH or $\mathrm{CRH}$ is applied for the evaluation of preterm adrenocortical function.

A wide range of ACTH doses from $0.5-36 \mu \mathrm{g} / \mathrm{kg}$ have been applied for stimulating cortisol secretion in preterm infants ${ }^{25)}$. Different time-points for blood sampling are necessary to identify the peak cortisol level ${ }^{26)}$. The ACTH test only gives information about the secretory capacity of the adrenals and not pituitary or hypothalamic insufficiency. In this regard, the pituitary-adrenal system can be tested by the CRH test. However, the use of CRH is not the ideal method to test the integrity of the HPA system. The insulin-induced hypoglycemia test is suitable for evaluating the integrity of the HPA axis. However, because of the risk of brain damage induced by hypoglycemia, experience with this test is very limited ${ }^{25)}$.

Most of the cortisol produced in the adrenal glands is excreted in the urine as tetrahydrocortisol and tetrahydrocortisone conjugated with glucuronic acid ${ }^{5,25)}$. Unconjugated cortisol represents $<1 \%$ of the adrenal secretion of this hormone in most situations ${ }^{5,25)}$. Therefore, the measurement of cortisol and its metabolite in 24-h urine specimens by chromatography and mass spectrometry is a reliable and noninvasive method of assessing cortisol production in preterm infants ${ }^{17}$. While such an approach primarily requires a reliable method of collecting $24-\mathrm{h}$ urinary specimens, a challenging task with regard to babies, the urine collection is performed by using disposable pure cellulose nappies from which the urine is recovered by hydraulic compression $^{17)}$.

Salivary cortisol measurement is a widely accepted alternative to the determination of cortisol levels in plasma or serum. The stress-free salivary collection for cortisol measurement has an advantage compared to plasma sampling because the adrenal cortex is responsive to the stress of venipuncture ${ }^{27,28)}$. Two methods of saliva collection have been used with preterm infants; using a commercial device to extract saliva from a small cotton ball and aspirating saliva using a small plastic tube ${ }^{28)}$. While some reports have suggested that salivary cortisol measurement is a reliable marker in critically ill subjects and preterm infants ${ }^{29-}$

${ }^{32)}$, its utility for preterm infants has not been confirmed ${ }^{33)}$. The ideal time to sample saliva after stress needs to be evaluated ${ }^{31)}$.

\section{ADRENAL INSUFFICIENCY IN PRETERM INFANTS}

Activation of the HPA axis is crucial to maintaining homeostasis in response to stress. While there is no evidence of clinical adrenocortical insufficiency in term infants, ill and preterm infants may have a decreased ability to produce adequate amounts of glucocorticoids.

Systemic hypotension is a common complication in sick preterm infants. While the cause of hypotension in the preterm infant is multifactorial, multiple studies of extremely low birth weight infants have demonstrated hypotension that is refractory to volume expanders and vasopressors but responds to glucocorticoids $^{34,35)}$. Recent studies have demonstrated low circulating levels of cortisol in preterm infants under stress, suggesting that the pathophysiology of systemic hypotension is associated with immaturity of the HPA axis ${ }^{17,21)}$.

Transient adrenocortical insufficiency of prematurity (TAP) is the term used to describe the clinical scenario in which preterm newborns in the immediate postnatal period have a normal or enhanced pituitary response but a transient inability of the adrenal glands to maintain cortisol homoeostasis ${ }^{36,37)}$. TAP is frequently associated with systemic hypotension and results from an immature HPA axis and a reduced capability of the adrenal glands to produce cortisol secondary to a deficiency of intermediate enzymes, such as $11 \beta$-hydroxylase, in the synthesis pathway $^{36,37)}$. TAP is typically transient, and adrenal function tends to return to normal by the end of the second week of life. Therefore, 
glucocorticoid-responsive hypotension is not considered to be a common phenomenon in this population beyond the second week of life. However, preterm infants sometimes develop lateonset glucocorticoid-responsive circulatory collapse ${ }^{21)}$. The clinical picture of late-onset adrenal insufficiency in preterm infants (AIP) is not a result of an absolute deficiency of cortisol production; it may instead be due to a limited ability to synthesize sufficient cortisol for the degree of clinical stress ${ }^{21)}$. Clinical signs suggesting AIP include hypotension, oliguria, hyponatremia, lung edema, an increased demand for oxygen treatment without infection, hypovolemia, anemia, and the reopening of a patent ductus arteriosus ${ }^{21)}$.

There are no definitive diagnostic criteria for AIP. A presumptive diagnosis can be made if there is a clinical picture that is compatible with adrenal insufficiency, an inappropriately low serum cortisol level for the clinical scenario, and a rapid recovery from signs of adrenal insufficiency after cortisol replacement. A serum cortisol level less than $15 \mu \mathrm{g} / \mathrm{dL}$ is one that is frequently used for the diagnosis of AIP. This level was determined following the proposed definition for relative adrenal insufficiency in critically ill adults and from the results of a study in critically ill term neonates that demonstrated improvement in hemodynamic parameters with hydrocortisone therapy in those patients with initial cortisol concentrations less than $15 \mu \mathrm{g} / \mathrm{dL}^{38,39)}$. An increase in cortisol of less than $9 \mu \mathrm{g} / \mathrm{dL}$ in response to low dose ACTH stimulation ( $1 \mu \mathrm{g} / \mathrm{kg}$ of synthetic ACTH) is also used for the diagnosis of AIP. However, neither baseline cortisol $<15 \mu \mathrm{g} /$ dL nor $\Delta$-cortisol $<9 \mu \mathrm{g} / \mathrm{dL}$ were associated with the presence of relative adrenal insufficiency between the fifth and seventh days of life in preterm infants ${ }^{40)}$. Some authors have recommended measuring the cortisol level in serum or saliva in response to a $\mathrm{CRH}$ test $(1 \mu \mathrm{g} / \mathrm{kg}$ of hCRH$)$ as a reliable method to evaluate the HPA axis in the preterm infant $t^{41,42)}$.

Hydrocortisone is greatly preferred over dexamethasone for

Table 1. Summary of Published Studies on Adrenal Insufficiency in Preterm Infants

\begin{tabular}{|c|c|c|c|c|c|}
\hline Study & $\mathbf{n}$ & $\begin{array}{c}\text { GA } \\
\text { (wks) }\end{array}$ & $\begin{array}{l}\text { Postnatal } \\
\text { age* }^{*} \\
\text { (d) }\end{array}$ & $\begin{array}{l}\text { Serum } \\
\text { cortisol }^{\dagger} \\
(\mu g / d L)\end{array}$ & Treatment \\
\hline Bourchier and Weston, $1997^{58)}$ & $\begin{array}{c}\text { HC: } 21 \\
\text { Dopamine: } 19\end{array}$ & VLBW & $<7$ & $\mathrm{ND}^{\|}$ & $\begin{array}{l}\text { HC } 2.5 \mathrm{mg} / \mathrm{kg} \text {, 4-6 hourly for } 48 \text { hours, followed by } 1.25 \\
\mathrm{mg} / \mathrm{kg} \text { six hourly for } 48 \text { hours, and then } 0.625 \mathrm{mg} / \mathrm{kg} \\
\text { for a further } 48 \text { hours before stopping treatment }\end{array}$ \\
\hline Gaissmaier and Pohlandt, 1999 ${ }^{59)}$ & 17 & 28 & 2 & ND & A single intravenous dose of dexamethasone $0.25 \mathrm{mg} / \mathrm{kg}$ \\
\hline Seri et al, $2001^{60)}$ & 21 & $26.9 \pm 3.9^{\ddagger}$ & $11.3 \pm 13.1^{\ddagger}$ & ND & $\begin{array}{l}\mathrm{HC} 2 \mathrm{mg} / \mathrm{kg} / \mathrm{d} \text { in } 16 \text { infants } \\
\mathrm{HC} 3-6 \mathrm{mg} / \mathrm{kg} / \text { day in } 5 \text { infants }\end{array}$ \\
\hline Noori et al, $2006^{61)}$ & 24 & $26(23-34)^{\S}$ & $2(1-24)^{\S}$ & ND & $\begin{array}{c}\text { Dexamethasone } 0.1 \mathrm{mg} / \mathrm{kg} \text { followed by } 0.05 \mathrm{mg} / \mathrm{kg} \\
\text { intravenously every } 12 \text { hours for } 5 \text { additional doses }\end{array}$ \\
\hline Ng et al, 2006 ${ }^{62)}$ & $\begin{array}{c}\text { HC: } 24 \\
\text { Placebo: } 24\end{array}$ & $<32$ & $11(8-15)^{\S}$ & ND & $\mathrm{HC} 1 \mathrm{mg} / \mathrm{kg}$ every $8 \mathrm{hr}$ for 5 days \\
\hline Masumoto et al, $2008^{21)}$ & 11 & $26.8 \pm 2.4^{\ddagger}$ & $13.1 \pm 4.1^{\ddagger}$ & $6.6 \pm 4.5^{\ddagger}$ & $\mathrm{HC} 1-2 \mathrm{mg} / \mathrm{kg} /$ dose \\
\hline Hochwald et al, 2010 & $\begin{array}{c}\text { HC: } 9 \\
\text { Placebo: } 9\end{array}$ & $<28$ & $<2$ & ND & $\begin{array}{l}\text { HC } 2 \mathrm{mg} / \mathrm{kg} \text { for the first dose followed by three } 6 \text { hourly } \\
\text { doses of } 1 \mathrm{mg} / \mathrm{kg} \text { and a further four doses of } 0.5 \mathrm{mg} / \mathrm{kg} \\
\text { giving a cumulative dose of } 7 \mathrm{mg} / \mathrm{kg} \text { in } 48 \mathrm{hr}\end{array}$ \\
\hline Choi et al, 2011 & 12 & $30.6 \pm 2.4^{\ddagger}$ & $19 \pm 7^{\ddagger}$ & $11.6 \pm 4.1^{\ddagger}$ & $\begin{array}{l}\mathrm{HC} 4 \mathrm{mg} / \mathrm{kg} / \text { day for } 1-2 \text { days } \rightarrow 2 \mathrm{mg} / \mathrm{kg} / \text { day for } 1-2 \text { days } \\
\quad \rightarrow 1 \mathrm{mg} / \mathrm{kg} / \text { day for } 1-2 \text { days }\end{array}$ \\
\hline Lee et al, $2011^{65)}$ & 16 & $28 \pm 2^{\ddagger}$ & $20 \pm 11^{\ddagger}$ & $5.6 \pm 2.5^{\ddagger}$ & $\mathrm{ND}$ \\
\hline Lee et al, $2013^{66)}$ & 44 & $26.0 \pm 1.9^{\ddagger}$ & $16.5(5-158)^{\S}$ & ND & $\begin{array}{l}\text { HC loading dose: } 3-5 \mathrm{mg} / \mathrm{kg} / \text { day } \rightarrow 3 \mathrm{mg} / \mathrm{kg} / \text { day } \rightarrow 1 \\
\mathrm{mg} / \mathrm{kg} / \text { day }\end{array}$ \\
\hline Shimokaze et al, $2015^{67)}$ & 14 & $<29$ & $21(18-32)^{\S}$ & $8.7(1.5-34.8)^{\S}$ & $\mathrm{HC} 2-5 \mathrm{mg} / \mathrm{kg} \rightarrow$ reduction of dosage (median 23 days) \\
\hline
\end{tabular}

Abbreviations: GA, gestational age; HC, hydrocortisone; VLBW, very low birth weight; ND, not described.

*Age of initiation of corticosteroid treatment.

${ }^{\dagger}$ Serum cortisol level at the time of clinical manifestation of adrenal insufficiency.

${ }^{\ddagger}$ Mean \pm standard deviation.

${ }^{\S}$ Median (range).

"ACTH stimulation tests were performed using Synacthen $35 \mu \mathrm{g} / \mathrm{kg}$ intravenously. 
the treatment of AIP because it has less of an effect on the suppression of growth and has both glucocorticoid and mineralocorticoid effects. Various dosages and durations of hydrocortisone therapy have been used for the replacement of AIP (Table 1). According to a Cochrane review, hydrocortisone might be as effective as dopamine when used as a primary treatment for hypotension. However, the long term safety data on the use of hydrocortisone in this manner was unknown ${ }^{43)}$. In addition, glucocorticoids were effective in treating refractory hypotension in preterm infants without an increase in short term adverse consequences $^{43)}$. Further studies to verify the diagnostic criteria, optimize treatment of AIP, and collect long term safety data are warranted.

\section{SCREENING FOR CONGENITAL ADRENAL HYPERPLASIA}

Congenital adrenal hyperplasia (CAH) due to 21-hydroxylase deficiency is an inherited metabolic disorder that affects 1 per 16,000 neonates ${ }^{44,45)}$. Mass screening of neonates for 21-hydroxylase deficiency identifies both male and female affected infants, prevents incorrect sex assignment, and decreases mortality and morbidity due to salt-wasting crisis. Most newborn screening programs measure 17-hydroxyprogesterone (17-OHP) from dried blood spots on filter paper. However, 17-OHP measurement in preterm infants has a high false-positive rate ${ }^{46)}$.

The mechanism underlying the high concentration of 17-OHP in preterm infants is not clearly understood because 21-hydroxylase is actively expressed in early mid-gestation and $3 \beta \mathrm{HSD}$ is expressed in late mid-gestation ${ }^{1}$. Possible explanations for the increased levels of 17-OHP in preterm infants include an increase in the conversion of cholesterol to pregnenolone due to increased ACTH from postnatal stress ${ }^{47}$, a decrease in the conversion of 11-deoxycortisol to cortisol due to a delayed expression of $11 \beta$-hydroxylase $\mathrm{e}^{19,48)}$, and a decrease in the excretion of steroid metabolites from the kidney ${ }^{45}$. Another probable explanation is that there is a crossed reaction in measuring 17-OHP with other steroid metabolites, such as 17-hydroxypregnenolone and its sulfated metabolites ${ }^{7,49)}$.

Specificity of newborn screening might be improved by using gestational age or birthweight to stratify subjects because $17-$ OHP levels are much better correlated with gestational age $\mathrm{e}^{50,51)}$. However, there are no universally accepted standards for strati- fying infants. Liquid chromatography-tandem mass spectrometry steroid profiling as a second-tier test on immunoassay results has also been introduced for reducing the burden of repeated tests for $\mathrm{CAH}$ screening ${ }^{52,53)}$. In addition, testing additional steroid profiles other than 17-OHP using liquid chromatography-tandem mass spectrometry is suggested to reduce the false-positive rate of $\mathrm{CAH}$ screening ${ }^{54)}$. One study, in which urinary steroid hormone metabolites were analyzed by gas chromatography-mass spectrometry, suggested that low $11 \beta$-hydroxylase activity accounted for the high 17-OHP level in preterm infants and that 21-deoxycortisol or its urinary metabolite was more specific than 17-OHP for the diagnosis of classical $\mathrm{CAH}^{48)}$.

On the other hand, antenatal corticosteroid administration can interfere with screening programs for $\mathrm{CAH}$ because corticosteroids are known to suppress the HPA axis ${ }^{55,56)}$. Because betamethasone and dexamethasone are similar in their ability to cross the placenta and suppress the fetal pituitary-adrenal axis, the use of antenatal corticosteroids can increase the risk for decreasing 17-OHP levels in the blood spot, thus leading to falsenegative results. The Lawson Wilkins Pediatric Endocrine Society and the European Society for Pediatric Endocrinology have recommended that premature newborns need serial measurements of 17-OHP to differentiate false-positive and negative results from affected infants with $\mathrm{CAH}^{50)}$.

Although false-positive and false-negative rates of screening for CAH remain high in preterm infants, there is a low risk of missing a case of CAH that could lead to a salt-wasting crisis in the neonatal intensive care unit. Rescreening at regular intervals combined with careful monitoring of the clinical status in preterm infants with elevated 17-OHP levels is recommended ${ }^{57)}$.

\section{CONCLUSION}

Adrenal hormones play various roles in somatic development and maintenance of homeostasis throughout the fetal and neonatal periods. Serum cortisol levels of preterm infants are similar to basal levels reported for healthy full-term neonates. However, a rise of cortisol production is absent during illness. While premature maturation of the HPA axis is suggested in preterm infants, the inappropriate cortisol value despite severe illness is due to immaturity of $11 \beta$-hydroxylase activity and an immature response of the brain to stress. Whereas abnormal 
clinical findings associated with adrenal dysfunction are not rare in preterm infants, the diagnostic criteria and optimal management have not yet been determined. Further research is required to improve understanding of the pathophysiology and management of adrenal dysfunction in the preterm infant.

\section{REFERENCES}

1) Mesiano S, Jaffe RB. Developmental and functional biology of the primate fetal adrenal cortex. Endocr Rev 1997;18:378-403.

2) Ng PC. The fetal and neonatal hypothalamic-pituitary-adrenal axis. Arch Dis Child Fetal Neonatal Ed 2000;82:F250-4.

3) Swanson JR, Sinkin RA. Transition from fetus to newborn. Pediatr Clin North Am 2015;62:329-43.

4) Watterberg KL. Adrenocortical function and dysfunction in the fetus and neonate. Semin Neonatol 2004;9:13-21.

5) Kronenberg HM, Melmed S, Polonsky KS, Larsen PR. Williams texbook of endocrinology. 11th ed. Philadelphia: Saunders, 2008:755-76.

6) Ishimoto H, Jaffe RB. Development and function of the human fetal adrenal cortex: a key component in the feto-placental unit. Endocr Rev 2011;32:317-55.

7) Pasqualini JR. Enzymes involved in the formation and transformation of steroid hormones in the fetal and placental compartments. J Steroid Biochem Mol Biol 2005;97:401-15.

8) Sperling MA. Pediatric endocrinology. 4th ed. Philadelphia: Saunders, 2014:471-92.

9) Watterberg KL. Adrenocortical function and dysfunction in the fetus and neonate. Semin Neonatol 2004;9:13-21.

10) Benediktsson R, Calder AA, Edwards CR, Seckl JR. Placental 11 beta-hydroxysteroid dehydrogenase: a key regulator of fetal glucocorticoid exposure. Clin Endocrinol 1997;46:161-6.

11) Murphy BE, Clark SJ, Donald IR, Pinsky M, Vedady D. Conversion of maternal cortisol to cortisone during placental transfer to the human fetus. Am J Obstet Gynecol 1974;118:538-41.

12) Hillman NH, Kallapur SG, Jobe AH. Physiology of transition from intrauterine to extrauterine life. Clin Perinatol 2012;39: 769-83.

13) Bird JA, Spencer JA, Mould T, Symonds ME. Endocrine and metabolic adaptation following caesarean section or vaginal delivery. Arch Dis Child Fetal Neonatal Ed 1996;74:F132-4.

14) Watterberg KL, Demers LM, Scott SM, Murphy S. Chorioamnionitis and early lung inflammation in infants in whom bronchopulmonary dysplasia develops. Pediatrics 1996;97:2105.

15) Watterberg KL, Scott SM, Naeye RL. Chorioamnionitis, cortisol, and acute lung disease in very low birth weight infants.
Pediatrics 1997;99:E6.

16) Bolt RJ, Van Weissenbruch MM, Popp-Snijders C, Sweep FG, Lafeber HN, Delemarre-van de Waal HA. Maturity of the adrenal cortex in very preterm infants is related to gestational age. Pediatr Res 2002;52:405-10.

17) Heckmann M, Hartmann MF, Kampschulte B, GackH, Bödeker $\mathrm{RH}$, Gortner L, et al. Cortisol production rates in preterm infants in relation to growth and illness: a noninvasive prospective study using gas chromatography-mass spectrometry. J Clin Endocrinol Metab 2005;90:5737-42.

18) Hanna CE, Keith LD, Colasurdo MA, Buffkin DC, Laird MR, Mandel SH, et al. Hypothalamic pituitary adrenal function in the extremely low birth weight infant. J Clin Endocrinol Metab 1993;76:384-7.

19) Hingre RV, Gross SJ, Hingre KS, Mayes DM, Richman RA. Adrenal steroidogenesis in very low birth weight preterm infants. J Clin Endocrinol Metab 1994;78:266-70.

20) Nykänen P, Heinonen K, Riepe FG, Sippell WG, Voutilainen R. Serum concentrations of adrenal steroids and their precursors as a measure of maturity of adrenocortical function in very premature newborns. Horm Res Paediatr 2010;74:358-64.

21) Masumoto K, Kusuda S, Aoyagi H, Tamura Y, Obonai T, Yamasaki C, et al. Comparison of serum cortisol concentrations in preterm infants with or without late-onset circulatory collapse due to adrenal insufficiency of prematurity. Pediatr Res 2008;63:686-90.

22) Alkalay AL, Klein AH, Nagel RA, Pomerance JJ. Evaluation of hypothalamic-pituitary-adrenal axis in premature infants treated with dexamethasone. Am J Perinatol 1996;13:473-7.

23) NgPC. Is there a "normal" range of serum cortisol concentration for preterm infants? Pediatrics 2008;122:873-5.

24) de Weerth C, Zijl RH, Buitelaar JK. Development of cortisol circadian rhythm in infancy. Early Hum Dev 2003;73:39-52.

25) Ranke MB. Diagnostics of endocrine function in children and adolescents. 3rd revised and extended ed. Basel: Karger, 2003: 54-6.

26) Karlsson R, Kallio J, Toppari J, Kero P. Timing of peak serum cortisol values in preterm infants in low-dose and the standard ACTH tests. Pediatr Res 1999;45:367-9.

27) Chiappin S, Antonelli G, Gatti R, De Palo EF. Saliva specimen: a new laboratory tool for diagnostic and basic investigation. Clin Chim Acta 2007;383:30-40.

28) Neu M, Goldstein M, Gao D, Laudenslager ML. Salivary cortisol in preterm infants: validation of a simple method for collecting saliva for cortisol determination. Early Hum Dev 2007;83:47-54.

29) Arafah BM, Nishiyama FJ, Tlaygeh $H$, Hejal R. Measurement of salivary cortisol concentration in the assessment of adrenal function in critically ill subjects: a surrogate marker of the circulating free cortisol. J Clin Endocrinol Metab 2007;92:2965- 
71.

30) Bettendorf M, Albers N, Bauer J, Heinrich UE, Linderkamp $\mathrm{O}$, Maser-Gluth C. Longitudinal evaluation of salivary cortisol levels in full-term and preterm neonates. Horm Res 1998; 50:303-8.

31) Calixto C, Martinez FE, Jorge SM, Moreira AC, Martinelli CE Jr. Correlation between plasma and salivary cortisol levels in preterm infants. J Pediatr 2002;140:116-8.

32) Grunau RE, Haley DW, Whitfield MF, Weinberg J, Yu W, Thiessen P. Altered basal cortisol levels at 3, 6, 8 and 18 months in infants born at extremely low gestational age. J Pediatr 2007; 150:151-6.

33) Maas C, Ringwald C, Weber K, Engel C, Poets CF, Binder G, et al. Relationship of salivary and plasma cortisol levels in preterm infants: results of a prospective observational study and systematic review of the literature. Neonatology 2014;105:312-8.

34) Colasurdo MA, Hanna CE, Gilhooly JT, Reynolds JW. Hydrocortisone replacementin extremely premature neonates with cortisol insufficiency. Clin Res 1989;37:180A.

35) Ward RM, Kimura RE, Rich-Denson C. Addisonian crisis in extremely premature neonates. Clin Res 1991;39:11A.

36) Ng PC, Lam CW, Fok TF, Lee CH, Ma KC, Chan IH, et al. Refractory hypotension in preterm infants with adrenocortical insufficiency. Arch Dis Child Fetal Neonatal Ed 2001;84:F122-4.

37) Ng PC, Lee CH, Lam CW, Ma KC, Fok TF, Chan IH, et al. Transient adrenocortical insufficiency of prematurity and systemic hypotension in very low birthweight infants. Arch Dis Child Fetal Neonatal Ed 2004;89:F119-26.

38) Fernandez E, Schrader R, Watterberg K. Prevalence of low cortisol values in term and near-term infants with vasopressorresistant hypotension. J Perinatol 2005;25:114-8.

39) Langer M, Modi BP, Agus M. Adrenal insufficiency in the critically ill neonate and child. Curr Opin Pediatr 2006;18:448-53.

40) Sari FN, Dizdar EA, Oguz SS, Andiran N, Erdeve O, Uras N, et al. Baseline and stimulated cortisol levels in preterm infants: is there any clinical relevance? Horm Res Paediatr 2012;77:12-8.

41) Ng PC, Wong GW, Lam CW, Lee CH, Wong MY, Fok TF, et al. The pituitary-adrenal responses to exogenous human corticotropin-releasing hormone in preterm, very low birth weight infants. J Clin Endocrinol Metab 1997;82:797-9.

42) Matsukura T, Kawai M, Marumo C, Iwanaga K, Yoshida K, Shibata M, et al. Diagnostic value of salivary cortisol in the $\mathrm{CRH}$ stimulation test in premature infants. J Clin Endocrinol Metab 2012;97:890-6.

43) Ibrahim H, Sinha IP, Subhedar NV. Corticosteroids for treating hypotension in preterm infants. Cochrane Database Syst Rev 2011:CD003662. doi: 10.1002/14651858.CD003662.pub4.

44) White PC, Speiser PW. Congenital adrenal hyperplasia due to 21-hydroxylase deficiency. Endocr Rev 2000;21:245-91.
45) Speiser PW, White PC. Congenital adrenal hyperplasia. N Engl J Med 2003;349:776-88.

46) Nordenstrom A, Wedell A, Hagenfeldt L, Marcus C, Larsson A. Neonatal screening for congenital adrenal hyperplasia: 17hydroxyprogesterone levels and CYP21 genotypes in preterm infants. Pediatrics 2001;108:E68.

47) Huysman MW, Hokken-Koelega AC, De Ridder MA, Sauer PJ. Adrenal function in sick very preterm infants. Pediatr Res 2000;48:629-33.

48) Kamrath C, Hartmann MF, Boettcher C, Wudy SA. Reduced activity of $11 \beta$-hydroxylase accounts for elevated $17 \beta$ hydroxyprogesterone in preterms. J Pediatr 2014;165:280-4.

49) Riepe FG, Mahler P, Sippell WG, Partsch CJ. Longitudinal study of plasma pregnenolone and 17-hydroxypregnenolone in full-term and preterm neonates at birth and during the early neonatal period. J Clin Endocrinol Metab 2002;87:4301-6.

50) Joint LWPES/ESPE CAH Working Group. Consensus statement on 21-hydroxylase deficiency from the Lawson Wilkins Pediatric Endocrine Society and the European Society for Paediatric Endocrinology. J Clin Endocrinol Metab 2002;87:404853.

51) Olgemöller B, Roscher AA, Liebl B, Fingerhut R. Screening for congenital adrenal hyperplasia: adjustment of 17-hydroxyprogesterone cut-off values to both age and birth weight markedly improves the predictive value. J Clin Endocrinol Metab 2003;88:5790-4.

52) Sarafoglou K, Gaviglio A, Hietala A, Frogner G, Banks K, McCann M, et al. Comparison of newborn screening protocols for congenital adrenal hyperplasia in preterm infants. J Pediatr 2014;164:1136-40.

53) Seo JY, Park HD, Kim JW, Oh HJ, Yang JS, et al. Steroid profiling for congenital adrenal hyperplasia by tandem mass spectrometry as a second-tier test reduces follow-up burdens in a tertiary care hospital: a retrospective and prospective evaluation. J Perinat Med 2014;42:121-7.

54) Janzen N, Peter M, Sander S, Steuerwald U, Terhardt M, Holtkamp U, et al. Newborn screening for congenital adrenal hyperplasia: additional steroid profile using liquid chromatography-tandem mass spectrometry. J Clin Endocrinol Metab 2007;92:2581-9.

55) Kari MA, Raivio KO, Stenman UH, Voutilainen R. Serum cortisol, dehydroepiandrosterone sulfate, and steroid-binding globulins in preterm neonates: effect of gestational age and dexamethasone therapy. Pediatr Res 1996;40:319-24.

56) Gatelais F, Berthelot J, Beringue F, Descamps P, Bonneau D, Limal JM, et al. Effect of single and multiple courses of prenatal corticosteroids on 17-hydroxyprogesterone levels: implication for neonatal screening of congenital adrenal hyperplasia. Pediatr Res 2004;56:701-5. 
57) Chung HR, Shin CH, Yang SW, Yun KA, Lee YA, Park SE, et al. Interpretation of screening for congenital adrenal hyperplasia in preterm infants. Korean J Pediatr 2008;51:616-21.

58) Bourchier D, Weston PJ. Randomised trial of dopamine compared with hydrocortisone for the treatment of hypotensive very low birth weight infants. Arch Dis Child Fetal Neonatal Ed 1997;76:F174-8.

59) Gaissmaier RE, Pohlandt F. Single dose dexamethasone treatment of hypotension in preterm infants. J Pediatr 1999;134:7015.

60) Seri I, Tan R, Evans J. Cardiovascular effects of hydrocortisone in preterm infants with pressor-resistant hypotension. Pediatrics 2001;107:1070-4.

61) Noori S, Siassi B, Durand M, Acherman R, Sardesai S, Ramanathan R. Cardiovascular effects of low-dose dexamethasone in very low birth weight neonates with refractory hypotension. Biol Neonate 2006;89:82-7.

62) Ng PC, Lee CH, Bnur FL, Chan IH, Lee AW, Wong E, et al. A double-blind, randomized, controlled study of a "stress dose" of hydrocortisone for rescue treatment of refractory hypo- tension in preterm infants. Pediatrics 2006;117:367-75.

63) Hochwald O, Pelligra G, Osiovich H. The use of hydrocortisone for the treatment of hypotension in VLBW infants. Pediatric Academic Conference Proceedings. Available from: http:// www.abstracts2view.com/pasall/. 2010:Abstract 504 .

64) Choi EJ, Sohn JA, Lee EH, Lee JY, Lee HJ, Chung HR, et al. Clinical picture of adrenal insufficiency-associated hypotension in preterm infants. J Korean Soc Neonatol 2011;18:82-8.

65) Lee JA, Choi CW, Kim EK, Kim HS, Kim BI, Choi JH. Lateonset hypotension and late circulatory collapse due to adrenal insufficiency in preterm infants with gestational age less than 32 weeks. J Korean Soc Neonatol 2011;18:211-20.

66) Lee WJ, Kim MY, Cho HJ, Lee JS, Son DW. Clinical features of late-onset circulatory collapse in preterm infants. Korean J Perinatol 2013;24:148-57.

67) Shimokaze T, Akaba K, Saito E. Late-onset glucocorticoidresponsive circulatory collapse in preterm infants: clinical characteristics of 14 patients. Tohoku J Exp Med. 2015;235:2418. 